\title{
Problems Research on Agricultural Listed Companies in China's
}

\section{Securities Market}

\author{
Yunlei Huo ${ }^{1, a}$ \\ ${ }^{1}$ Jilin Business and Technology College, Changchun, Jilin, 130507 \\ ${ }^{a}$ email
}

Keywords: Agriculture, Listed Company, Diversification

\begin{abstract}
China is a large agricultural country, but the Chinese agricultural listed companies play a very small role in the capital market. The central document in 2013 on the innovation of agricultural management system as the main line, focus on the development of new agricultural business entities, focus on the development of multi service subject, strengthen the construction of new agricultural management system of intensive, professional, organizational and social combination, to accelerate the development of modern agriculture and promote the integration of urban and rural development to provide the system guarantee. Therefore, how to expand the scale and strength of China's agricultural listed companies in the capital market to occupy a place in the capital market will be worthy of attention.
\end{abstract}

How to become a big agricultural country, to a large extent depends on how to develop China's agricultural related companies, especially agricultural listed companies. Chinese agricultural listed companies should strengthen the construction of its soft power and hard power of national policy document, the path of diversification become bigger and stronger, to play a greater value for the development of China economic development and capital market.

\section{Current Situation of China's Agricultural Listed Companies}

Small Scale and Single Variety. Overall, the agriculture in China showing a big industry, small companies, the level of industrialization is relatively low, the growth of agricultural stocks is relatively weak. Agricultural listed companies by the end of 2012, a total of more than and 60, the maximum size of the listed company's market value of about 20 billion. Investor concern is low, investment enthusiasm is poor, the stock is not active. They are distributed in more than and 20 provinces, scattered distribution, its main business and products are subject to the local agriculture and the basic condition of natural resource constraints, single product. Once by the local natural or man-made weather damage caused by the management is a big blow for the company.

Low Level of Scientific and Technological Content. The additional value of agricultural listed companies' production is low, and the gross profit rate of related agricultural listed companies has been low. The profitability of agricultural listed companies can be reflected from the sales net profit margin, main business profit margin, total assets yield (ROA), sales gross profit margin, return on equity (ROE) and other indicators. According to statistics, more than and 60 listed companies in 2012 net sales, the main business profit rate, the rate of return on total assets (ROA), gross margin, net assets yield (ROE) were 8.06\%, 5.72\%, 5.12\%, 13.57\%, 3.94\%. Compared with other industries, 
the average line is below the average. Sales of low margin that agricultural listed companies low technology content, rough machining and the extensive management brings to the enterprise profit is very low, and the rate of return on total assets low cost high, the management level and the listed companies during the cost control should be further improved.

\section{Countermeasures to Solve the Problems}

Develop Diversified Listed Companies of Agriculture. The traditional agriculture refers to animal husbandry and fishery, including planting, breeding, irrigation, fertilization, harvest drying, spraying medicine based agricultural production, agricultural listed companies should be out of the narrow sense of the range of agricultural go big agriculture development path, development ways such as agricultural, agricultural products and agricultural circulation; development of farmers the training of rural finance, the development of tourism agriculture; way, leisure farm; development way of agricultural technology promotion, agricultural business chain services, diversified, multi angle listed companies to enhance their own strength, strengthen the listed company "moat" the depth and breadth.

Reinforce Science and Technology Innovation Ability and Government Policy Support. First, clear agricultural listed companies in the direction of scientific and technological innovation. Focus on long-term development, ahead of the deployment of the technical field of the agricultural frontier and strengthen basic research, and strive to occupy an important position in the world of agricultural science and technology frontier; second, countries should support the cultivation, reproduction and dissemination of "the integration of agricultural listed companies, accelerate the establishment of enterprises as the main body of the commercialization of new products and create new mechanism. Optimize the layout of agricultural enterprises to improve the market access threshold, and promote agricultural listed companies mergers and acquisitions, to encourage large companies through mergers and acquisitions, equity and other ways to enter. The establishment of the agricultural development fund, cultivate a group of "breeding, cultivation, promotion and integration of large backbone of listed companies, listed companies to support the establishment of breeding platform and the advantages of scientific research units, research institutes, colleges and universities to encourage scientific research personnel and listed companies share. Increase of animal and plant breeding project implementation efforts, strengthen the construction of northwest, southwest, Hainan and other advantages of agricultural products base, encourage listed companies and farmer cooperatives to jointly set up production bases of raw materials is relatively concentrated and stable in grain production of new varieties of introduction and demonstration county construction field. To meet the conditions of the production of high-quality agricultural insurance pilot, increase financial assistance efforts. Improve the variety evaluation and protection, exit system, strengthen agricultural production and operation of administrative license management, to crack down on counterfeit and shoddy, deck infringement, panic buying illegal arbitrage. Strengthen basic research in agriculture, agricultural biological gene regulation and molecular breeding, forestry, animal and plant resistance mechanism, farmland resource utilization, forestry ecological restoration, pest control, biological safety and the safety of agricultural products and other aspects of a number of major breakthroughs in basic theory and methods.

Make Full Use of Regional and Other Advantages. We should follow the principle of consumer market and use the nearest raw material principle, northeast listed companies can use their own fertile land, agriculture developed the advantage of development of grain production in the food processing and manufacturing and mining rich forestry resources, doing fine; the Inner Mongolia area listed companies to use their own natural prairie animal husbandry development 
advantages beautiful and Chinese planting business, while improving the related dairy products, meat processing technology; Xinjiang agricultural listed companies in Xinjiang using the natural climate advantages in the development of fruit, cotton, and other advantages of the products; the eastern coastal areas of listed companies are making full use of regional economic development, strong financial advantage in the development of rural finance and agricultural services, there is development freshwater fisheries and seafood processing industry; the Central Plains area of the listed companies to strengthen aquaculture and food Basket works, etc.. Products can not be single, to meet the needs of the growing urbanization of the population from multiple angles.

Consturct Logistics Channel belonging to the Agricultural Listed Company. Many agricultural products due to logistics conditions, listed company's resources and geographical advantages can not be transformed into economic advantage, marketing of agricultural products caused by poor transportation costs increase, low efficiency, at the same time in the transportation, storage, handling, loss and damage often occurs in cases brought great losses to the listed company. So the listed company should rely on the resources and geographical advantages, to carry out the company sales of various agricultural supply chain operation; run directly in the company's supermarket chain or chain stores, centralized distribution to the company's products and materials; in accordance with the needs of chain operation, development scale, specialization, standardization of production, improve product quality form, quantity; help the development condition of the wholesale market of agricultural products distribution center, to improve the distribution chain enterprises or other services, relying on the development of agricultural products wholesale market chain operation; establish the company of agricultural products screening, classification, packaging, preservation, processing, packaging and processing manufacturing company formed products; the logistics company to establish channel products efficiently through the establishment of freezing and cold storage and warehousing and freight forwarding, product distribution and transportation Road, to achieve maximum efficiency in many ways..

\section{References}

[1] Qin Zhigang, Fu Limin, Machen, Li Dongsheng, Journal of Anhui Agricultural Sciences, Vol. 39(2011) No 10, p. 6262-6264

[2] Huang Peigen, Liao Yijing, Journal of Longdong University, Vol. 25 (2014) No 3, p.46-48

[3] Li Yu, Communication of Finance and Accounting, Vol. 26 (2015) No 3, p.31-33

[4] Li Dongsheng, Qin Zhigang, Friends of Accounting, Vol. 29(2011) No 6, p.56-58 